\title{
Esophageal manometry in systemic sclerosis: findings and association with clinical manifestations
}

\author{
(iD) Juliana Markus ${ }^{1}$ \\ Rogério de Melo Costa Pinto ${ }^{2}$ \\ D Abadia Gilda Buso Matoso' \\ (iD) Roberto Ranza
}

\begin{abstract}
1. Departamento de Clínica Médica - Faculdade de Medicina, Universidade Federal de Uberlândia - Uberlândia, MG, Brasil 2. Doutor em Genética, Faculdade de Matemática, Universidade Federal de Uberlândia, Uberlância, MG, Brasil 3. Hospital de Clínicas da Universidade Federal de Uberlândia, Uberlândia, MG, Brasil
\end{abstract}

http://dx.doi.org/10.1590/1806-9282.66.1.48

\section{SUMMARY}

INTRODUCTION: Systemic sclerosis (SSC) is an autoimmune disorder that affects several organs of unknown etiology, characterized by vascular damage and fibrosis of the skin and organs. Among the organs involved are the esophagus and the lung.

OBJECTIVES: To relate the profile of changes in esophageal electromanometry (EM), the profile of skin involvement, interstitial pneumopathy (ILD), and esophageal symptoms in SSC patients.

METHODS: This is an observational, cross-sectional study carried out at the SSC outpatient clinic of the Hospital de Clínicas of the Federal University of Uberlândia. After approval by the Ethics Committee and signed the terms of consent, 50 patients were initially enrolled, from 04/12/2014 to 06/25/2015. They were submitted to the usual investigations according to the clinical picture. The statistical analysis was descriptive in percentage, means, and standard deviation. The Chi-square test was used to evaluate the relationship between EM, high-resolution tomography, and esophageal symptoms.

RESULTS: $91.9 \%$ of the patients had some manometric alterations. $37.8 \%$ had involvement of the esophageal body and lower esophageal sphincter. $37.8 \%$ had ILD. $24.3 \%$ presented the diffuse form of SSC. No association was found between manometric changes and clinical manifestations (cutaneous, pulmonary, and gastrointestinal symptoms).

CONCLUSION: The present study confirms that esophageal motility alterations detected by EM are frequent in SSC patients, but may not be related to cutaneous extension involvement, the presence of ILD, or the gastrointestinal complaints of patients.

KEYWORDS: Systemic Sclerosis, Esophagus, Interstitial Lung Disease, Manometry

\section{INTRODUCTION}

Among collagen disorders, systemic sclerosis (SS) is a devastating disease with a profound impact on life expectancy and a probability of death $3.5^{1}$ greater than the general population. Mortality varies according to the type of cutaneous involvement, diffuse or limited (more prevalent), and is more unfavorable in the diffuse form. The main cause of mortality in SS is cardiopulmonary involvement ${ }^{\mathbf{1}}$. The most frequent pulmonary manifestation is interstitial lung disease (ILD), present between $57-86 \%{ }^{1}$ of these individuals. Gastroesophageal reflux is one of the mechanisms involved in ILD'. 
The involvement of the gastrointestinal tract (GIT) is present in approximately $80 \%$ of individuals with $\mathrm{SS}^{2}$. The segment of the GIT more frequently involved is the esophagus, affected in 50-90\% of patients with $\mathrm{SS}^{3}$. Due to the precocity of esophageal involvement even without classic symptoms, its presence should be investigated ${ }^{4}$ since its consequences, such as bronchoaspiration, predispose pulmonary fibrosis, and Barrett's esophagus ${ }^{5}$. In addition, the symptoms of esophageal involvement (SEI), such as dysphagia, heartburn, and acid regurgitation, have a negative impact on the quality of life of patients with $\mathrm{SS}^{6}$.

SEI may be absent in up to $50 \%$ of patients with involvement of the organ documented by complementary tests ${ }^{4}$. The investigation of the changes in esophageal motility is done mainly by esophageal electromanometry $(\mathrm{EM})^{4}$, which can find subtle alterations in the motility of the organ. In the ME, the scleroderma esophagus classically presents loss of motility of the distal third of the esophageal body (EB) and hypotonicity of the lower sphincter ${ }^{7}$, but these changes are not always simultaneous nor exclusive of $\mathrm{SS}^{8}$.

The medical literature describes the association between a higher frequency of esophageal abnormalities in patients with limited cutaneous involvement, as expressed by Leroy's criteria in $1988^{\circ}$. The association between SS esophagopathy and the diffuse cutaneous presentation of the disease, the severity of pulmonary damage $^{10}$, the pattern of the antinuclear factor, and specific antibodies ${ }^{9.11}$ remains controversial ${ }^{7}$.

The present study was performed in SS patients who attended the Clinical Hospital of the Federal University of Uberlândia (HC-UFU). Its objective is to correlate; in these individuals, the profile of ME changes with the type of cutaneous involvement with ILD and SEI.

\section{PATIENTS AND METHOD}

\section{Patients}

This is an observational, cross-sectional study conducted at the SS outpatient clinic of HC-UFU from December 2014 to June 2015, approved by the Ethics Committee (Platform Brasil, Opinion: 929.011). We invited to participate in the study patients of the Rheumatology Outpatient Clinic of HC-UFU aged over 18 years and with diagnosed SS according to the criteria of ACR/EULAR $2013^{12}$. The patients were separated based on the forms of cutaneous involvement, diffuse or limited, according to the criteria defined by Leroy ${ }^{13}$.
The clinical and laboratory characterization was carried out based on the data obtained from the medical charts, which were as follows: sex, age, year of the first symptom of the disease, presence of pyrosis, dysphagia and reflux of gastric contents (SEI), Raynaud's phenomenon (RP), presence of anti-centromere antibody, and presence of the antibody anti-topoisomerase1, serology for Chagas Disease (two methods: hemagglutination and ELISA), echocardiogram, treatments with nifedipine, cyclophosphamide and bosentan, concomitance of diabetes and hypothyroidism.

In the analysis of the echocardiograms, pulmonary hypertension was considered when recorded in the examiner report and with measures of pulmonary artery pressure greater than $35 \mathrm{mmHg}^{14}$. In the retrospective analysis, RP or thickening of the fingers noticed by the patient was considered as the first symptom of $\mathrm{SS}^{15}$.

All 58 individuals with a SS diagnosis who attended the Rheumatology Outpatient Clinic of HC-UFU were invited to participate in the study; 50 agreed and signed the Informed Consent Form (ICF).

\section{Esophageal Manometry}

All EMs were performed by the same gastroenterologist (Matoso, AGB). EM was performed, after a $6 \mathrm{~h}$ fasting, with an electromanometer with a water perfusion catheter with four radial channels and four channels separated $5 \mathrm{~cm}$ apart (Alacer Bio-São Paulo). The normality criteria for the esophagus manometry findings were the following: Pressure of the upper sphincter of the esophagus (USE): $30-180 \mathrm{mmHg}$; lower esophageal sphincter (LES): 10-34 mmHg; Number of peristaltic waves: 8-10 (greater than 80\%). LES hypotonia was defined when the pressure was lower than $10 \mathrm{mmHg}$, and aperistalsis, as the absence of peristaltic function in the lower esophageal body (EB). Hypocontractility was characterized as more than $30 \%$ of waves not conducted and/or a mean amplitude in the distal esophagus of less than $30 \mathrm{mmHg}^{16}$.

\section{High-resolution Computed Tomography (HRCT)}

Tomographic findings consistent with pulmonary impairment related to SS were considered the description of glass opacities, honeycombing of the parenchyma, or fibrosis in the lung bases in HRCT, and confirmed by the physician. Any one of these descriptions given by the radiologist was considered and related to SS. The HRCT was carried out in 
several different services with reports from different radiologists ${ }^{17}$.

\section{Statistical analysis}

We performed a descriptive statistical analysis in percentages, means, and standard deviations to describe the sample. To assess the relationship between EM, HRCT, and esophageal symptoms (SEI), we used the Chi-square test. All analyses were performed using the SPSS software version 20.0. We considered a p-value $<0.05$ to be significant.

\section{RESULTS}

\section{General data of the population}

Of the 50 patients included initially, only 37 underwent HRCT and EM and had their data analyzed in the present study. Of these, $30(81.1 \%)$ are coming from Uberlandia. The mean age at the time of inclusion in the study was 50.22 years, with a minimum of 25 and a maximum of 70 years. The average time between the first manifestations of the disease and attending the specialized service was 5.2 years (SD of 8.48 years). Two individuals did not present the onset of the disease with RP. Other demographic data and clinical characterization are described in Table 1.

\section{Esophageal Manometry}

Of the 37 EM patients studied, three had completely normal test results; therefore, 34 (91.9\%) had some abnormality. There were 14 (37.8\%) individuals with concomitant abnormalities in the EB and the LES. Fifteen (40.6\%) patients presented exclusive involvement of the EB. Four patients had exclusive involvement of the LES: two had hypotonia, and two presented the LES hypertonia. In the series, we found two individuals with LES hypertonia concurrent with waves not conducted by the EB. One patient presented the upper sphincter with a tendency to low amplitude. In Figure 1, we can see a normal EM and, in figure 2, one often found among SS patients.

\section{High-resolution Computed Tomography (HRCT)}

In the present study, $14(37.8 \%)$ patients presented ILD, of these seven were anti- topoisomerase1 positive. In the group of ILD patients, seven (50\%) presented diffuse cutaneous SS and the other seven (50\%) the limited cutaneous presentation. In addition to ILD, there were seven patients with other findings, such as calcified nodules, atelectasis, blisters, and results compatible with pulmonary emphysema. Dilation of the Eb was described in four cases.

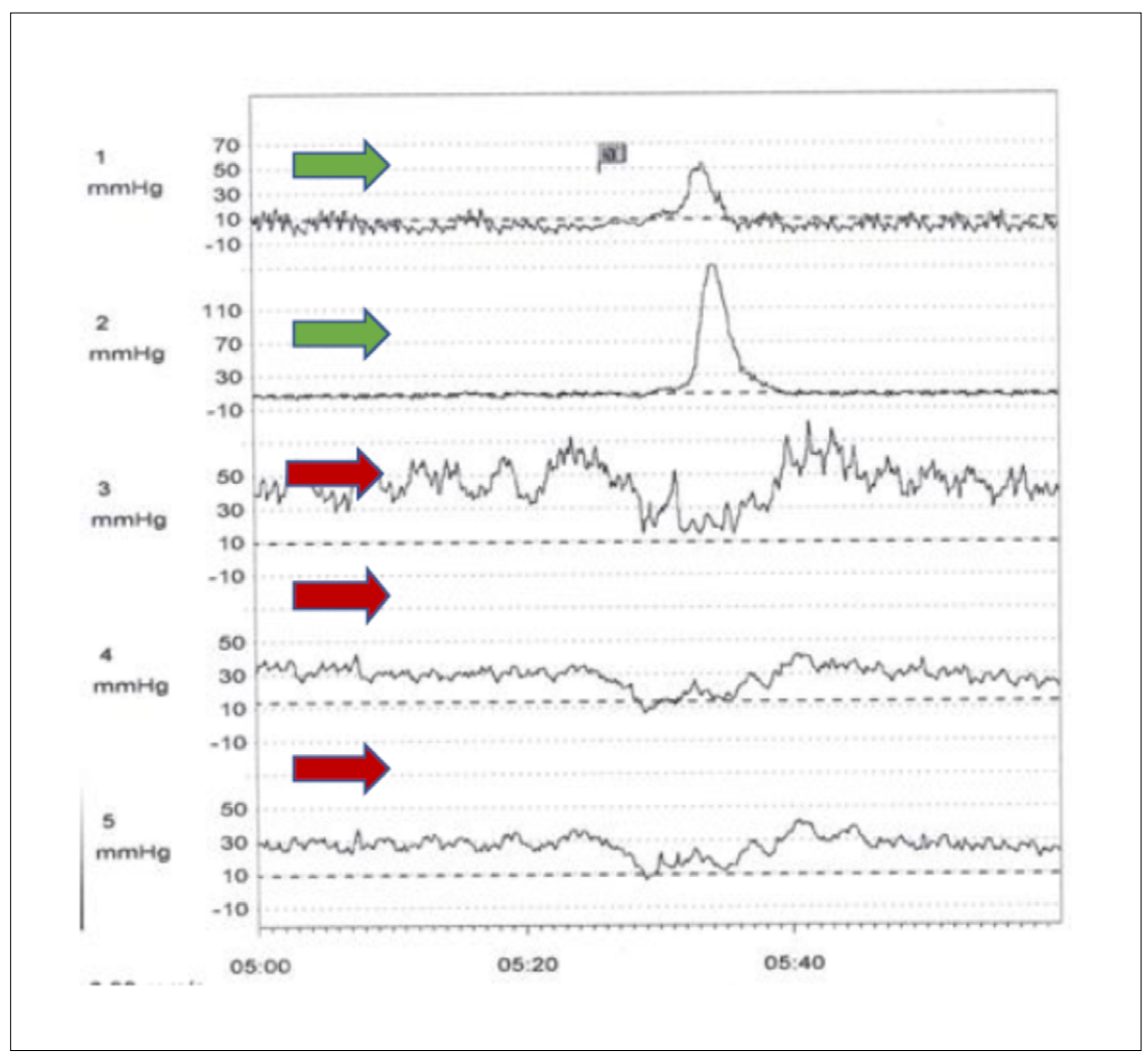

FIGURE 1- NORMAL CONVENTIONAL ESOPHAGEAL ELECTROMANOMETRY. PERISTALTIC CONTRACTIONS IN THE ESOPHAGEAL BODY (GREEN ARROWS), NORMOTONIC LOWER ESOPHAGEAL SPHINCTER WITH ADEQUATE RELAXATION DURING SWALLOWING (RED ARROWS 
FIGURE 2. ESOPHAGEAL MANOMETRY IN A PATIENT WITH SYSTEMIC SCLEROSIS. HYPOCONTRACTILITY OF THE ESOPHAGEAL BODY WITH ABSENCE OF WAVES OF CONTRACTION (GREEN ARROWS), HYPOTONIA OF THE LOWER ESOPHAGEAL SPHINCTER WITH NORMAL RELAXATION DURING SWALLOWING (RED ARROWS).

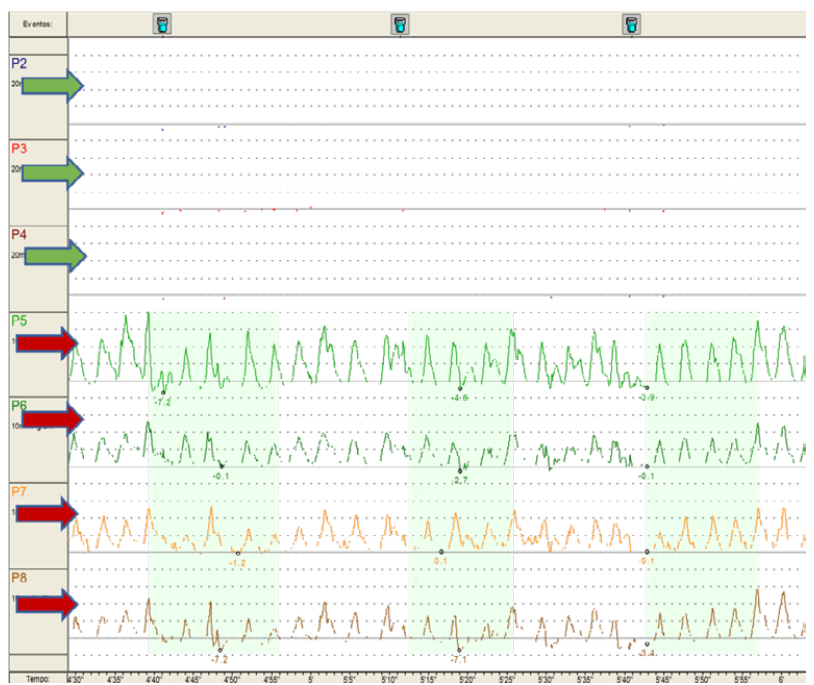

The relationship between cutaneous involvement and the manometry findings

The distribution of the type of cutaneous involvement and the manometry findings were analyzed, and no significant difference was found in the frequency of abnormal EM in both groups, not even when the abnormalities of the EB or the LES (p:0.999) analyzed in isolation.

The relationship between pulmonary involvement and the manometry findings

No statistically significant correlation was found between manometry abnormalities exclusive to the EB or in association with LES, and ILD ( $p: 0.736)$ were found.

The relationships of esophageal manifestations (ES), distribution by type of cutaneous involvement and EM and HRCT findings

Only 06 (16.21\%) individuals did not present SEI. The relationship between abnormalities in the SEI and ES showed no statistical correlation; there were 34 patients with EM abnormalities and 31 with SEI ( $p$ : 0.70). The presence of SEI also did not correlate with the exclusive involvement of the EB, which totaled 15 (40.5\%) cases, among which 13 (35.1\%) had SEI ( $p$ : $0.087)$. There was also no statistically relevant correlation in the association of patients with SEI and individuals with hypotonia of the LES concomitant to the absence of waves in the EB; there were 12 (32.4\%) symptomatic cases with that relationship, in comparison to the other 19 (51.3\%) symptomatic patients with EM without the involvement of the LES ( $p$ : 0.152).

There was no statistically significant correlation between the presentation of cutaneous involvement and SEI; there were $23(62.1 \%)$ individuals with limited cutaneous SS and symptomatic and $8(21.6 \%)$ cases of diffuse cutaneous SS also symptomatic ( $p$ :0.154). The ones with SEI also did not correlate with the presence of ILD; there were $12(32.4 \%)$ patients with symptoms and ILD, in comparison with 19 (51.3\%) individuals with symptoms and without ILD ( $p$ : 0.999).

Among the patients who presented abnormalities in the EM, 15 (40.5\%) were taking a calcium channel blocker, and 19 (51.3\%) were not. Therefore, there was no relationship between the manometry findings and the use of calcium channel blockers ( $p$ : 0.678).

\section{DISCUSSION}

The higher incidence of SS in females and greater prevalence of the limited cutaneous presentation are universal ${ }^{18}$. In this study, $92 \%$ of women had SS. The

TABLE 1. DEMOGRAPHIC, CLINICAL, AND IMMUNOLOGICAL DATA OF 37 PATIENTS WITH SS IN 2015.

\begin{tabular}{l|l} 
Variables and epidemiological data & $\begin{array}{l}\text { Results (data are in num- } \\
\text { bers (\%), except where } \\
\text { indicated otherwise }\end{array}$ \\
\hline $\begin{array}{l}\text { Age at the onset of the disease } \\
\text { (years), mean ( } \pm \text { SD) } \\
\text { Female }\end{array}$ & $\begin{array}{l}52.21(12.06) \\
34(92)\end{array}$ \\
\hline $\begin{array}{l}\text { Form of cutaneous presentation } \\
\text { Limited }\end{array}$ & $28(75.7)$ \\
\hline \multicolumn{1}{c}{ Diffuse } & $9(24.3)$ \\
\hline $\begin{array}{l}\text { Esophageal symptoms (dysphagia, } \\
\text { pyrosis, and/or regurgitation) }\end{array}$ & $31(83.8)$ \\
\hline Abnormal esophageal manometries & $34(91.9)$ \\
\hline $\begin{array}{l}\text { Interstitial lung disease } \\
\text { Pulmonary hypertension on echocar- } \\
\text { diogram }\end{array}$ & $14(37.8)$ \\
\hline Comorbidities \\
Diabetes mellitus
\end{tabular}

*Seven patients didi not undergo the examination, sample of 30 patients with Echocardiogram 
age of onset of the disease varies depending on the region of the world evaluated ${ }^{18}$. In this sample, the population showed a later onset, at 52.21 years, than that found in studies in Brasil (50.5 years ${ }^{19,20}$ ) and Latin America, which has studies showing disease onset with an average age of 35.8 years ${ }^{21}$.

The high prevalence of abnormal manometry findings in the present study is in agreement with the literature $^{3.4}$. The classic dysmotilities of SS in EM are hypomotility with waves not conducted on the esophageal body concomitant with hypotonia of the lower esophageal sphincter, which occurred in $35.15 \%$ of patients in this series. However, $37.8 \%$ of the patients had only involvement of the esophageal body, without the involvement of the EIR. And 10.8\% had LES abnormalities without the involvement of the esophageal body. The higher prevalence of the involvement of the esophageal body in relation to the abnormalities of the EIR, in isolation, were already known ${ }^{8.22}$. There are reports that SS starts in the esophagus body ${ }^{23}$. It is believed that arteriole changes of the vasa nervorum would lead successively to the three stages of esophageal involvement: neuropathy, myopathy, and fibrosis, which may explain the higher frequency of impairment of the EB musculature than that of the LES, corroborated by the findings of the present study ${ }^{23}$. But there is no way to tell how much time of disease progression is required to present the concomitant involvement of the esophageal body and of the LES, or if all individuals evolve in the same way. It is important to emphasize that the patients of the group studied had a mean time of 5.2 years since the first symptom until the diagnosis of SS.

Both diabetes mellitus ${ }^{23}$ and hypothyroidism with myxedema ${ }^{23}$ can cause esophageal abnormalities detectable by EM. It is not possible to determine in this study, due to the small number of cases with overlapping, if indeed these entities have contributed to precipitate, worsen, or not the abnormalities in the EM. In the same way, the role of calcium channel blockers on esophageal motility is controversial. That influence is controversial, but this study corroborates the findings of a previous one ${ }^{22}$, which also found no association between the use of calcium channel blockers and the manometry findings of esophageal dysmotility or hypotonia of the LES.

In the series analyzed, there was one case of involvement of the upper sphincter of the esophagus, an unusual fact in $\mathrm{SS}^{24}$, which was associated with the concomitant presence of inflammatory myopathy since it is formed by striated skeletal muscles ${ }^{24}$.
In this group, there were two EM with achalasia, not usual among the classic findings of $\mathrm{SS}^{22}$. There is probably more than one etiopathogenic mechanism that causes damage in the esophagus in SS. The immune-mediated condition of SS is among the causes of esophageal structural damage ${ }^{11}$. Chagas disease was excluded in these cases ${ }^{25}$.

No statistically significant relationship was found between esophageal body abnormalities and of the LES alone with limited and/or diffuse cutaneous subgroup. There is also no relationship between the involvement of the body and the LES with the diffuse or limited cutaneous presentation of SS. This fact is in agreement with the study developed by Calderaro at $\mathrm{a}^{22}$, whose patients and geographical location are similar to those of this study. Unlike what was suggested by Leroy, in $1988^{\circ}$, who correlated the limited cutaneous presentation with esophageal abnormalities.

There is a concern regarding the consequences of gastric content aspiration on the pulmonary parenchyma, leading to ILD. Pulmonary damage is present in $57-86 \%$ of patients with $\mathrm{SS}^{2}$. Studies have suggested an association of severe esophageal disease in patients with the presence of anti-topoisomerase $1^{10}$. This, in turn, would be associated with a greater prevalence of ILD ${ }^{10}$. In this study, we recorded $37.8 \%$ of cases of ILD and $24.3 \%$ of cases of anti-topoisomerase 1 . The high prevalence of esophageal abnormalities did not correlate with a higher frequency of abnormalities on computed tomography scans in this study. Even when analyzed separately, abnormalities exclusive to the esophageal body, or in association with LES abnormalities, showed no statistically significant association with ILD. That is perhaps because the frequency of ILD in our population was lower than that described in the literature, which might have influenced in the absence of this association.

In patients analyzed, the presence of SEI was not statistically correlated with none of the manometry abnormalities analyzed. The absence of correlation between the presence of esophageal abnormalities in $\mathrm{EM}$ and SEI is well described in the literature since ES is less frequent than EM abnormalities. Perhaps this can be explained by the slow progression of the disease, or by the lack of more sensitive instruments for the clinical investigation of the patient.

This study was conducted at a referral center in the countryside of Brasil and presented as a limitation a small number of individuals with SS. Thus, the data may not be extrapolated, despite corroborating 
Brazilian studies conducted previously. There is also a limitation regarding the technique of $\mathrm{EM}$, which was performed with conventional equipment (not high resolution), but that is the equipment available in most national services. However, this study stands out for demonstrating that there is no correlation of clinical data such as cutaneous involvement and/or SEI that denote the profile of EM abnormalities. In addition, segmental abnormalities in the esophagus in EM do not correlate with ILD. These facts require special attention from the medical team because these patients may have relevant esophageal and lung structural changes without necessarily presenting a classic clinical pattern of the disease. There is no need to wait for diffuse cutaneous SS to investigate ILD, nor is it necessary for the esophagus body to be affected concomitantly with the LES for ILD screening to be conducted. It is also not necessary to wait for SEI to investigate the organ.

\section{CONCLUSION}

In the population with SS evaluated in this study, esophageal abnormalities in EM were frequent. However, no distribution pattern was found regarding segmental alterations, isolated or concomitant, of the esophagus with the type of cutaneous involvement. It was also not possible to establish a relationship of a specific manometry pattern and the presence of ILD. The existence of clinical gastrointestinal symptoms did not correlate with the diffuse or limited cutaneous pattern, or with manometry alterations of body and LES, isolated or associated, even when ILD was present. This study is relevant because it indicates the need for special attention in the care of patients with SS since they need to be screened for esophageal complications without SEI. It is also necessary to assess the existence of ILD, regardless of the type of cutaneous involvement and the intensity of the esophageal involvement.

\section{Contribution of the authors}

Juliana Markus - main author, responsible for the text; Rogério de Melo Costa Pinto - Supported the statistical analysis of the data and supervised the writing.

Abadia Gilda Buso Matoso - Supported the research and the writing of the draft; Roberto Ranza - Designed the methodology and supported the review of the article.

\section{RESUMO}

INTRODUÇão: A esclerose sistêmica (ES) é uma doença autoimune que afeta vários órgãos de etiologia desconhecida, caracterizada por dano vascular e fibrose da pele e órgãos. Entre os órgãos envolvidos estão o esôfago e o pulmão.

OBJETIVOS: Relacionar o perfil das alterações na eletromanometria (ME), o perfil de acometimento da pele, a pneumopatia intersticial (PI) e os sintomas esofágicos em pacientes com ES.

MÉTODO: Trata-se de um estudo observacional, transversal, realizado no ambulatório de SSC do Hospital das Clínicas da Universidade Federal de Uberlândia. Após aprovação pelo Comitê de Ética e assinatura dos termos de consentimento, 50 pacientes foram inicialmente convidados, de 04/12/2014 a 25/06/2015. Eles foram submetidos às investigações usuais de acordo com o quadro clínico. A análise estatística foi descritiva em porcentagem, média e desvio padrão. O teste Qui-quadrado foi utilizado para avaliar a relação entre ME, tomografia de alta resolução e sintomas esofágicos.

RESULTADOS: 91,9\% dos pacientes apresentaram alterações manométricas. 37,8\% tinham envolvimento do corpo esofágico e do esfíncter esofágico inferior. 37,8\% tinham IP. 24,3\% apresentaram a forma difusa da ES. Não há associação entre alterações manométricas e manifestações clínicas (sintomas cutâneos, pulmonares e gastrointestinais).

CONCLUSÃO: O presente estudo confirma que as alterações da motilidade esofágica detectadas pela EM são frequentes em pacientes com SSC, mas podem não estar relacionadas ao envolvimento cutâneo, à de DPI ou às queixas gastrointestinais dos pacientes.

PALAVRAS-CHAVE: Escleroderma sistêmico, Esôfago, Doenças pulmonares intersticiais, Manometria

\section{REFERENCES}

1. Elhai M, Meune C, Boubaya M, Avouac J, Hachulla E, Balbir-Gurman A, et al. Mapping and predicting mortality from systemic sclerosis. Ann Rheum Dis. 23 de 2017;

2. Savarino E, Bazzica M, Zentilin P, Pohl D, Parodi A, Cittadini G, et al. Gastroesophageal reflux and pulmonary fibrosis in scleroderma: a study using pH-impedance monitoring. Am J Respir Crit Care Med. 2009;179(5):408-13.
3. Lepri G, Guiducci S, Bellando-Randone S, Giani I, Bruni C, Blagojevic J, et al. Evidence for oesophageal and anorectal involvement in very early systemic sclerosis (VEDOSS): report from a single VEDOSS/EUSTAR centre. Ann Rheum Dis. 2015;74(1):124-8.

4. Gyger G, Baron M. Systemic Sclerosis: Gastrointestinal Disease and Its Management. Rheum Dis Clin N Am [Internet]. 2015 [citado 15 de fevereiro de 
2017];41(3):459-73. Disponível em: http://www.sciencedirect.com/science/ article/pii/S0889857X15000289

5. Calvet X. Oesophageal disease: gastroesophageal reflux disease, Barrett's oesophagus,achalasia and eosinophilic oesophagitis. Gastroenterol Hepatol. 2016;39 Suppl 1:47-52.

6. Crowell MD, Umar SB, Griffing WL, DiBaise JK, Lacy BE, Vela MF. Esophageal Motor Abnormalities in Patients With Scleroderma: Heterogeneity, Risk Factors, and Effects on Quality of Life. Clin Gastroenterol Hepatol Off Clin Pract J Am Gastroenterol Assoc 2017;15(2):207-213.e1.

7. Kimmel JN, Carlson DA, Hinchcliff M, Carns MA, Aren KA, Lee J, et al. The association between systemic sclerosis disease manifestations and esophageal high-resolution manometry parameters. Neurogastroenterol Motil Off J Eur Gastrointest Motil Soc.2016;28(8):1157-65.

8. Tsianos EB, Drosos AA, Chiras CD, Moutsopoulos HM, Kitridou RC. Esophageal manometricfindings in autoimmune rheumatic diseases: is scleroderma esophagus a specific entity? Rheumatol Int. 1987;7(1):23-7.

9. LeRoy EC, Black C, Fleischmajer R, Jablonska S, Krieg T, Medsger TA, et al. Scleroderma (systemic sclerosis): classification, subsets and pathogenesis. J Rheumatol. 1988;15(2):202-5.

10. Steen VD, Medsger TA. Severe organ involvement in systemic sclerosis with diffuse scleroderma. Arthritis Rheum. 2000;43(11):2437-44.

11. Kawaguchi $Y$, Nakamura $Y$, Matsumoto I, Nishimagi E, Satoh T, Kuwana $M$, et al. Muscarinic-3 acetylcholine receptor autoantibody in patients with systemic sclerosis:contribution to severe gastrointestinal tract dysmotility. Ann Rheum Dis. 2009;68(5):710-4.

12. van den Hoogen F, Khanna D, Fransen J, Johnson SR, Baron M, Tyndall A, et al. 2013 Classification Criteria for Systemic Sclerosis: An American College of Rheumatology/European League Against Rheumatism Collaborative Initiative: ACR/EULAR Classification Criteria for SSc. Arthritis Rheum [Internet] 2013 [citado 10 de fevereiro de 2017];65(11):2737-47. Disponível em: http:// doi.wiley.com/10.1002/art.38098

13. LeROY EC, Medsger TA. Criteria for the classification of early systemic sclerosis. | Rheumatol [Internet]. 2001 [citado 13 de fevereiro de 2017];28(7):15731576. Disponível em: http://www.jrheum.org/content/28/7/1573.short

14. Thakkar V, Stevens WM, Moore OA, Nikpour M. Performance of screening algorithms in systemic sclerosis-related pulmonary arterial hypertension: a systematic review. Intern Med ). 2013;43(7):751-60.

15. Bellando-Randone S, Matucci-Cerinic M. Very Early Systemic Sclerosis and Pre-systemic Sclerosis: Definition, Recognition, Clinical Relevance and Future Directions. Curr Rheumatol Rep. 2017;19(10):65.

16. Spechler SI, Castell DO. Classification of oesophageal motility abnormalities. Gut. 2001;49(1):145-51.

17. Matucci-Cerinic M, D'Angelo S, Denton CP, Vlachoyiannopoulos $P$, Silver R. Assessment of lung involvement. Clin Exp Rheumatol. 2003;21(3 Suppl 29):S19-23.

18. Barnes J, Mayes MD. Epidemiology of systemic sclerosis: incidence, prevalence, survival, risk factors, malignancy, and environmental triggers. Curr Opin Rheumatol. 2012;24(2):165-70.

19. Horimoto AMC, Matos ENN, Costa MR da, Takahashi F, Rezende MC, Kanomata LB, et al. Incidência e prevalência de esclerose sistêmica em Campo Grande, Estado de Mato Grossodo Sul, Brasil. Rev Bras Reumatol [Internet]. 2017;57(2):107-14. Disponível em: http://www.sciencedirect. com/science/article/pii/S0482500416300729

20. Sampaio-Barros PD, Bortoluzzo AB, Marangoni RG, Rocha LF, Del Rio APT, Samara AM, et al. Survival, causes of death, and prognostic factors in systemic sclerosis: analysis of 947 Brazilian patients. J Rheumatol [Internet]. 2012 [citado 10 de fevereiro de 2017];39(10):1971-1978. Disponível em: http://www.jrheum.org/content/39/10/1971.short

21. Gottschalk P, Vásquez R, López PD, Then J, Tineo C, Loyo E. Esclerodermia en el Caribe: características en una serie de casos dominicana. Reumatol Clínica [Internet]. 2014 [citado 10 de fevereiro de 2017];10(6):373-9. Disponível em:http://linkinghub.elsevier.com/retrieve/ pii/S1699258X14000448

22. Calderaro DC, de Carvalho M a. P, Moretzsohn LD. Esophageal manometry in 28 systemic sclerosis Brazilian patients: findings and correlations. Dis Esophagus Off J Int Soc Dis Esophagus. 2009;22(8):700-4.

23. Smout A, Fox M. Weak and absent peristalsis. Neurogastroenterol Motil Off J Eur Gastrointest Motil Soc. 2012;24 Suppl 1:40-7.

24. Jung M, Bonner A, Hudson M, Baron M, Pope J, on behalf of the Canadian Scleroder. Myopathy is a poor prognostic feature in systemic sclerosis: results from the CanadianScleroderma Research Group (CSRG) cohort. Scand I Rheumatol [Internet]. 2014 [citado 18 de fevereiro de 2017];43(3):217-20. Disponível em: http://www.tandfonline.com/doi/full/10.3109/03009742. 2013.868512

25. Silva LC, Vicentine FPP, Herbella FAM. High resolution manometric findings in patients with Chagas' disease esophagopathy. Asian Pac J Trop Med. 2012;5(2):110-2. 
Regarding the article "Esophageal manometry in systemic sclerosis: findings and association with clinical manifestations" with DOI number: https:// doi.org/10.1590/1806-9282.66.1.48, published in Journal of the Brazilian Medical Association, 2020;66(01), page 48, figure 1 changed from:

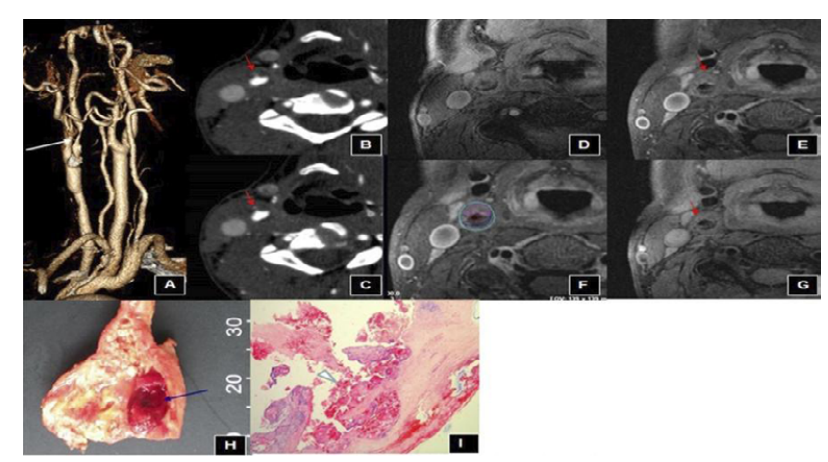

FIGURE 1. NORMAL CONVENTIONAL ESOPHAGEAL ELECTROMANOMETRY. PERISTALTIC CONTRACTIONS IN THE ESOPHAGEAL BODY (GREEN ARROWS), NORMOTONIC LOWER ESOPHAGEAL SPHINCTER WITH ADEQUATE RELAXATION DURING SWALLOWING (RED ARROWS)

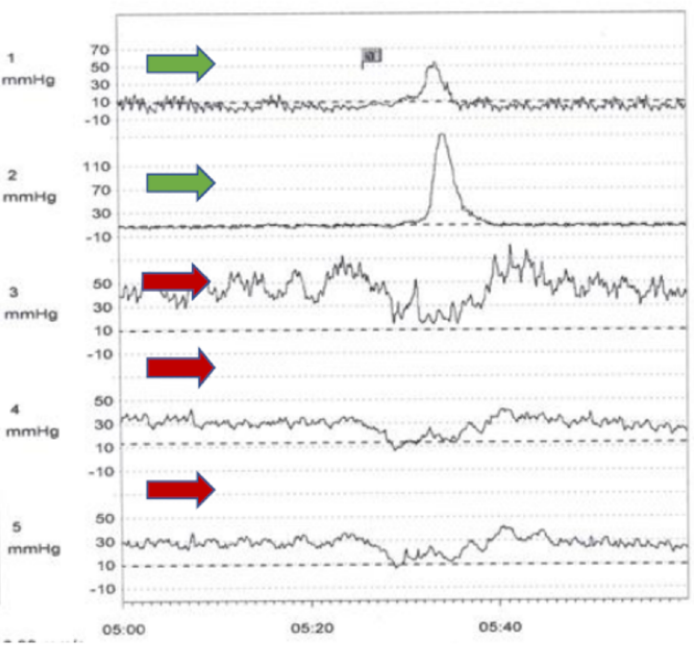

FIGURE 1- NORMAL CONVENTIONAL ESOPHAGEAL ELECTROMANOMETRY. PERISTALTIC CONTRACTIONS IN THE ESOPHAGEAL BODY (GREEN ARROWS), NORMOTONIC LOWER ESOPHAGEAL SPHINCTER WITH ADEQUATE RELAXATION DURING SWALLOWING (RED ARROWS

To 